\title{
Komunikasi Pembangunan Agama Dalam Membangun Toleransi Agama (Analisis Sistem dan Aktor)
}

\author{
Oleh : Hasan Sazali ${ }^{1}$
}

\begin{abstract}
Religious development is an important constellation of national development. To address the spirit of pluralism and religious phenomenon today, communication of religion development has become a scientific concept approach of several alternative science. Communication of religious development is a communication process which is carried out to execute the plan in religious development by a state. This paper analyzes the problems of religious development using system analysis and actors as an approach to build logical thinking to the current situation.
\end{abstract}

\begin{abstract}
Abstrak : Pembangunan agama merupakan salah satu bahagian yang penting dalam konstelasi pembangunan nasional. Untuk menyikapi semangat pluralisme serta fenomena keberagamaan saat ini, komunikasi pembangunan agama menjadi suatu pendekatan konsep ilmu pengetahuan dari beberapa alternatif ilmu pengetahuan yang ada. Komunikasi pembangunan agama merupakan suatu proses komunikasi yang dilakukan untuk melaksanakan rencana pembangunan dalam bidang agama oleh suatu negara. Tulisan ini menganalisis persoalan pembangunan agama dengan memakai analisis sistem dan aktor sebagai suatu pendekatan dalam membangun logika berpikir untuk melihat situasi saat ini. Kata Kunci : Komunikasi Pembangunan Agama, Sistem, Aktor
\end{abstract}

\section{Pendahuluan}

Pemerintah sebagai pemegang kendali kepemimpinan nasional telah memberikan sejumlah aturan perundangan yang apabila ditaati oleh masyarakat, akan menjadi sarana pemersatu bangsa yang kaya akan perbedaan ini. Akan tetapi pemerintah tidak bisa berjalan sendiri menciptakan dan menjaga kerukunan ini, mengingat hal ini banyak menyangkut masalah keyakinan dan prinsip-prinsip yang dianut masyarakat. Tokoh agama sebagai orang yang dipandang dan diteladani oleh kelompok masyarakat tertentu memiliki posisi strategis mengajak masyarakatnya hidup dalam kerukunan. Satu hal yang penting adalah

1 Hasan Sazali Dosen di Fakultas Dakwah dan Komunikasi UIN Sumatera Utara.Kandidat Dokootr Penyuluhan Komunikasi Pembangunan, Universitas Gadjah Mada (UGM) Yogyakarta. Email sazalihasansazal.ma@yahoo.co.id. Hp 081361572954 
pemerintah, tokoh agama dapat berperan sebagai fasilitator untuk menjembatani komunikasi dan kepentingan di dalam kelompok masyarakatnya yang beragam. Meminimalisir benturan antar kelompok yang berbeda, akan tetapi bukan berarti menghindarkan kontak dan komunikasi antara kelompok-kelompok berbeda dalam masyarakatnya. Justru berusaha membuat sesuatu secara terus menerus dalam melibatkan kelompok-kelompok yang ada, sehingga akan membentuk satu tujuan bersama yang mengikat mereka.

Untuk itu perlu dilihat apa yang menjadi persoalan dalam membangun toleransi agama selama ini, apakah sistem yang dibangun oleh Pemerintah melalui regulasi selaku aktor tidak dapat berperan sebagaimana mestinya, atau aktor-aktor yang terlibat dalam proses komunikasi pembangunan agama ${ }^{2}$ kompetensi mereka masih dipertanyakan, baik itu kompetensi theologis maupun kompetensi sosiologis, begitu juga dengan pendekatan sistem komunikasi dalam penyampaian konten regulasi. Menurut Penulis itu menjadi based-on bagi pemerintah, tokoh agama dalam mengkomunikasi issu-issu keberagamaan dalam realita sosial yang dibingkai dari semangat sistem regulasi yang dibuat oleh Pemerintah. Dalam tulisan ini penulis melihat perlunya suatu pendekatan kajian komunikasi dalam perspektif sistem dan aktor. Dalam tulisan ini juga akan memaparkan studi kasus dari hasil penelitian terkait dengan peran pemerintah dalam melakukan penguatan toleransi.

\section{Komunikasi Pembangunan Agama}

Tidak dapat disangkal bahwa pluralism (termasuk agama) adalah kenyataan. Istilah pluralisme ${ }^{3}$ berasal dari akar kata latin, plus, pluris,

2 Proses komunikasi pembangunan agama, dimulai dari bagaimana kompetensi aktor dalam memahami konten regulasi terkait dengan toleransi agama, atau konten pembangunan agama, bagaimana strategi dalam memahami kondisi sosial kultural masyarakat, begitu juga dengan metode penggunaan media dalam menyampaikan pesan-pesan pembangunan agama. Proses terbit harus memiliki indikator yang dapat dijadikan sebagai alat ukur dalam menganalisis berhasil tidaknya suatu pesan pembangunan agama, sekaligus merumuskan bentuk monitoring dan evaluasi terhadap proses pesan pembangunan agama yang direncanakan, maupun yang sudah dilakukan. Sehingga mempermudah bagi setiap aktor pembangunan untuk mengevaluasi keberhasilan atau kegagalan dari suatu program pembangunan agama, sehingga keberlangsungan pembangunan agama dapat terencana, dan tersistem dengan baik.

3 Pluralism (Pluralisme) Istilah ini mengandung tiga dekade yang berbeda dalam ilmu sosial. Salah satunya dielaskan secara ringkas berikut ini. Pluralisme dalam pengertian pertama merujuk pada pola institusional dalam masyarakat preindustrial non-Barat di bawah kekuasaan kolonial atau pasca-kolonial. Masyarakat plural adalah sebuah konsep 
yang secara harfiah berarti; lebih dari satu. Dalam pengertian filosofisnya, pluralism adalah pemahaman atau ajaran yang mengacu kepada adanya kenyatan yanglebih dari satu individu. Sebagai demikian, secara mendasar dicegah adanya pemutlakan, baik dalam pemikiran maupun dalam sikap. Senantiasa harus disadari bahwa tidak mungkin bahwa kenyataan yang mahakaya itu direduksi hanya menjadi satu-satunya kenyataan. Setiap individu misalnya mempunyai keunikan, juga dalam cara berpikir, berpersepsi, dan bertindak sehingga memutlakan hanya kepada satu cara berpikir, berpersepsi dan bertindak saja adalah suatu perkosaan terhadap hak-hak individu yang bersangkutan. Dari kacamata sosiologi, pluralisme mengacu kepada keberbagaian kelompok di dalam masyarakat, dan sebagai demikian juga mempunyai pandangan yang beraneka terhadap apa yang secara sosial dipahaminya dan dikehendakinya. ${ }^{4}$

Salah satu hal yang mewarnai dunia dewasa ini adalah pluralism keagamaan, demikian ungkap Coward ${ }^{5}$ Pluralisme merupakan sebuah fenomena yang tidak mungkin dihindari. Manusia hidup dalam pluralism dan merupakan bagian dari pluralisme itu sendiri, baik secara pasif maupun aktif, tak terkecuali dalam hal keagamaan. Pluralisme keagamaan merupakan tantangan khusus yang dihadapi agama-agama dunia dewasa ini ${ }^{6}$. Dan seperti pengamatan Coward setiapagama muncul dalam lingkungan yang plural ditinjau dari sudut agama dan membentuk dirinya sebagai tanggapan terhadap pluralisme tersebut.

yang diusulkan oleh J.S. Furnivall (1948) dan dikembangkan lebih lanjut oleh L.Kurper dan M.G. Smith kelompok-kelompok sosial yang mengatur diri sendiri dan saling berhubungan akan hidup berdampingan, namun masing-masing kelompok mempunyai eksistensi komunal nyang berbeda. Kelompok semacam ini secara eksternal dihubungkan oleh Negara dan pasar.Lihat. William Outhwaite, The Blackwell Dictionary Of Modern Social Thought, Terjemahan, Ensiklopedi Pemikiran Sosial Moderen, Jakarta, Kencana Prenada Media Group, Cet. I, 2008, hlm. 630.

4 Lihat. De Grote Oosthoek, Encyclopedie en Woordenboek, Deeln16, Oosthpek's Uitgeversmaatschappij BV, Utrechht, 1976, hlm. 100-101.

Coward, Pluralisme dan Tantangan Agama-agama, Yogyakarta: Kanisius, 1989, hlm. 5.

6 Persoalan di sekitar reaksi dan respon terhadap gerakan pluralisme agama di Indonesia masih berkepanjangan, boleh jadi akan sepanjang perkembangan masyarakat, yaitu masyarakat Indonesia yang plural termasuk plural dari segi pemahaman dan sikap terhadap apa yang dimaksudkan dengan pluralisme agama. Persoalan tidak berkisar hanya pada soal konsep, pemahaman dan wacana, tapi juga sikap, bagaimana menghargai, menerima dan mempraktekkan apa yang dimaksud dengan pluralisme aga dalam interaksi hidup sehari-hari. Lihat. Djohan Effendi, Pluralisme Dan Kebebasan Beragama, Yogyakarta, Institut DIAN/Interfide, Cet.IV, 2013, hlm. v 
Untuk menyikapi semangat pluralisme tersebut dari sudut pandang sosiologi agama, komunikasi pembangunan agama menjadi suatu pendekatan konsep ilmu pengetahuan dari beberapa alternatif ilmu pengetahuan yang ada. Komunikasi pembangunan agama ${ }^{7}$ merupakan suatu peroses komunikasi yang dilakukan untuk melaksanakan rencana pembangunan dalam bidang agama oleh suatu negara. Dalam konteks tulisan ini pembangunan agama dalam bidang toleransi umat beragama, yang dimulai dari sikap terhadap pesan komunkasi yang dilakukan oleh komunikator, isi pesan (regulasi toleransi agama), bentuk penyampaian pesan, pendekatan penyampaian pesan, dan evaluasi terhadap pesan yang disampaikan.

Perhatian khusus bagi berbagai kalangan keagamaan. Sejak paruh abad kedua dialog antar agama-agama secara umum dan lintas agama islam-kristen secara khusus, banyak dilakukan oleh berbagai kalangan baik yang berupa kelompok maupun lembaga keagaam secara legal, yang berupa kajian dalam forum lokal, nasional, bahkan internasional, dengan model seminar maupun konferensi.

Banyak buah positif yang dapat dipetik dari forum-forum seperti diatas. Pertama, dengan berkumpulnya orang yang secara dasar bangunan teologi keimanan berbeda, membuat tali persaudaraan lebi mengental, bahkan mampu mengubah paradigma miring terhadap agama atau aliran lain. Dikisahkan pada suatu pertemuan penjamuan wakil pemuka agama di Roma, Italia pada tahun 1994, meliputi penganut agama Hindu, Budha, Kristen, Islam, Yahudi dan tokoh-tokoh agama penting lain berkumpul dalam suatu majlis dan terlihat begitu antusias, saling berjabat tangan dan bahkan ada yang mencium tangan Paus. ${ }^{8}$

Kedua. Menumbuhkan kesadaran personal dan simpatisan terhadap pemeluk agama lain. Semisal dilingkungan Islam barat, dimana memori sejarah tentang tragedi keagamaan telah membentuk "mindset" dan penyikapan negatif atas agama islam dan orang muslim. Bahkan, sampai sekarang pemaknaan Islam di Barat masih menjadi hal yang tabu. Terkait dengan hal ini, tak ayal jika kemudian muncul pusat-pusat kajian lintas agama di dunia Barat yang bertujuan meningkatkan toleransi

7 Hasan Sazali. Penguatan Toleransi Agama dalam Komunikasi Pembangunan Agama Studi Pemerintah Kota Bogor dan Yogyakarta Disertasi, Jurusan Penyuluhan dan Komunikasi Pembangunan, sekolah Pascasarjana Universitas gadjah Mada Yogyakarta, 2015, hlm. 115

8 bttp:// wnw.jabarantha.co.cc/2011/06/ membangun-komunikasi-lintas-agama.html. di akses 3 Januari 2014. 
dan simpatisan terhadap pemahaman dan pengakuan antar agama lain. Ketiga, Lompatan metodologis pemahaman dalam studi agama-agama. Salah satu kelemahan pemahaman keagamaan adalah kecenderungan menyakini bahwa agama tertentu dijadikan sebagai standar kebenaran mutlak. Sementara kebenaran agama lain nihil bahkan sesat. Fanatisme agama ini, justru menjebak para pengikutnya apatis terhadap pluralisme agama dan menganggap agama lain adalah musuh. Dengan kata lain, agama telah dijadikan baju identitas bukan sebagai sumber kebenaran (esensi). Untuk itu, di perlukan metodologi baru terkait dengan pemahaman 'salah-kaprah' seperti ini. Yakni, dengan menganggap agama yang dianut adalah sebagai usaha mencari kebenaran dan jangan mengklaim bahwa agama kita paling benar dan agama lain sesat. ${ }^{9}$

Komunikasi pembangunan agama di Indonesia terkesan serimonial, tidak mampu menyentuh eksistensi kehidupan keberagamaan di Indonesia. Hal ini terlihat dari tahun ke tahun makin banyak terjadi konflik agama, apa itu antar agama maupun inter agama,masih segar dalam ingatan kita, kasus perusakan masjid di Tolikara, perusakan gereja di Aceh Singkil, begitu juga sweeping yang dilakukan oleh sekelompok masyarakat mengatas namakan agama tertentu terkait masjid-masjid yang tidak memiliki IMB di wilaya Sulawesi Utara. Persoalannya sampai saat ni belum ada solusi yang dibangun dalam pendekatan komunikasi pembangunan agama, menjadi pertanyaan bagi kita, apa yang menyebabkan kondisi ini terjadi? Kemungkinan ada beberapa pendekatan yang dapat kita lihat untuk melihat beberapa dari sekian banyak persoalannya dalam pendekatan metode keilmuan di antaranya; Lemahnya penerapan sistem regulasi yang dijalankan oleh Pemerintah dalam memberikan rasa aman bagi pemeluk agama dalam menjalankan keyakinannya, hilangnya peran aktor apakah Pemerintah selaku kelembagaan dalam menjalankan sistem biokrasi, maupun tokoh agama. Pada saat ini masyarakat kita sedang mengalami ketidak percayaan yang tinggi bahkan sudah sampai pada level kronis terhadap para pemimpin, ini terlihat salah satunya dari dinamika sosial keagamaan yang terjadi selalu berujung pada konflik. 


\section{Komunikasi Pembangunan Agama dalam Pendekatan Sistem dan Aktor.}

\section{Pengertian Sistem dan Aktor}

Untuk menjelaskan apa itu teori sistem, pertama-tama kita perlu memahami konsep sistem. Seorang ahli teori sistem Luhmann, David J. Krieger, memberi penjelasan yang menarik. Menurutnya jika kita mulai dengan awal, awal itu tentulah suatu chaos, suatu keadaan tidak terdeferensiasi. Seperti terjadinya dunia, suatu sistem terjadi dari diferensiasi itu. Menurut Luhman, apa yang kita sebut masyarakat tidak lain dari sistem-sistem sosial yang bersifat autopoiesis itu. Sistem-sistem sosial membentuk dirinya sendiri dengan membedakan diri (self-differentiation) dari lingkungannya (envrironment). Lingkungan di sini segala sesuatu yang tidak termasuk sistem. Ciri utama lingkungan adalah kompleksitas atau chaos atau noise. Lingkungan selalu lebih komplek dari sistem itu sendiri. Kompleksitas dari lingkungan itulah yang direduksi oleh sistem, sehingga sistem juga dapat didefenisikan sebagai reduksi atau kompleksitas. Dengan mereduksi kompleksitas itu, maka sistem membedakan dirinya dari lingkungan. ${ }^{10}$ Bila reduksi kompleksitas itu tidak behasil, maka sistem tidak terbentuk, dan dengan demikian, yang ada adalah lingkungan dengan segala kompleksitasnya.

Reduksi kompleksitas ini mengakibatkan bahwa sistem dan lingkungannya berelasi secara paradoksial. Sistem membentuk dirinya. Tapi pembentukan diri itu tidak berlangsung dalam kekosongan. Sistem itu membentuk dirinya dengan memanfaatkan "material" yang terdapat dalam lingkungannya.Tanpa ada lingkungan yang chaos dan kompleks, maka tidak ada sistem karena sistem tidak dapat "menciptakan materialnya dari dirinya sendiri". Dengan kata lain, lingkungan juga mempengaruhi bagaimana sistem itu terbentuk, tapi bagaimana pengaruh itu berlangsung atau sampai sejauh mana lingkungan itu menjalankan pengaruhnya terhadap sistem, itu tidak tergantung dari lingkungan, melainkan dari otonomi sistem tersebut. Sistem itulah melakukan seleksi dan menentukan bagaimana ia harus memanfaatkan "material" yang terdapat dalam lingkungan dalam rangka membentuk dirinya sendiri. ${ }^{11}$

Luhman mengatakan bahwa konsep sistem sebagai autopoesis tidak meniadaan konsep struktur. Sistem adalah totalitas jumlah elemen-

${ }^{10}$ Lihat. Fitzgerald K. Sitorus, Masyarakat Sebagai sistem-Sistem Autopoiesis, Tentang Teori Sistem Sosial Nikhas Lumann. Dalam. Jurnal Filsafat, Driyarkara, Kebaruan Teori Sistem Niklas Luhman, Thn.XXIX no.3/2008, hlm. 23-24.

${ }^{11}$ Ibid 
elemen dan relasi mereka satu sama lain. Relasi antar elemen atau struktur itu penting, sebab bila relasi itu tidak ada, maka yang terdapat bukanlah sistem, melainkan agregat, campuran atau tumpukkan elemenelemen. Sistem dalam konsepsi Luhman juga menagndung struktur namun ia tidak bersifat a priori dan determinan, sebagaimana dalam teori-teori strukturalisme.Menurut Luhman, struktur itu berfungsi sebagai pedoman internal dalam sistem, yakni untuk mengatur fungsi elemen-elemen sistem. ${ }^{12}$

Untuk melihat teori aktor, menarik jika kita melihat bagaimana teori rational choice, yang pada awal mulanya merupakan teori-teori yang dikembangkan dalam kajian matematika ekonomi. Dengan pilihan konsep-konsep rasional dinama aktor memiliki peran dalam menentukan pilihannya. Seiring perkembangannya, pandangan para penganut ekonomi modern mengenai konsep rasionalitas mengalami pergeseran dari utility-maximization based menjadi consistency-based. Contoh sederhana dari prinsip ini misalnya ketika seseorang diberi pilihan $\mathrm{x}$ dan $\mathrm{y}$, kemudian dia memilih $\mathrm{x}$, dapat dikatakan bahwa x merupakan opsi yang dapat memberikan keuntungan maksimal bagi dirinya. Kondisi ini merupakan gambaran dari prinsip utility-maximization based. Kemudian, individu tersebut dihadapkan kembali pada pilihan $\mathrm{x}, \mathrm{y}$, dan z. Maka, individu tersebut dikatakan rasional apabila dia memilih antara $\mathrm{x}$ atau $\mathrm{z}$, dan bukan $\mathrm{y}$. Kondisi ini menunjukkan gambaran dari prinsip consistency-based, sehingga secara ringkas dapat dikatakan bahwa rasionalitas individu ditentukan dari konsistensi internalnya dalam menentukan pilihan. Gagasan ini pula yang menarik Samuelson (1938) untuk mengkonstruksi teori consumer behavior yang menempatkan konsistensi atas pilihan sebagai aksiom pertamanya. Samuelson lebih lanjut menguji konsistensi internal melalui Weak Axiom of Revealed Preference (WARP).

Sejumlah kritik diajukan terhadap kedua gagasan di atas. Asumsi utility-maximization dianggap terlalu egois sehingga diharapkan norma sosial dan kultural dapat membatasi egoisme tersebut. Di sisi lain, asumsi consistency-based dianggap kebal terhadap norma, mengingat norma tidak berpengaruh pada konsistensi. Pada tataran yang lebih strategis, kondisi yang lebih kompleks terjadi pada rasionalitas pilihan yang melibatkan interaksi di antara beberapa individu. ${ }^{13}$

12 Ibid

${ }^{13}$ Kaushik Basu, Preludo to Political Economy, A Study of The Social and Political Foundation of Economics. Oxford. hlm. 36-37. 
Dari penjelasan sistem dan aktor di atas, Komunikasi pembangunan agama merupakan suatu bentuk komunikasi dan bagian penting untuk terbentuknya masyarakat komunikatif ${ }^{14}$, apalagi terhadap masyarakat yang plural dengan agama yang plural. Untuk itu, perlu dibentuk forum komunikasi, ruang publik yang demokratis, bebas dari dominasi dan hegemoni satu pihak, di mana pelaku-pelaku kesadaran yang terbuka, matang, komunikasi lintas agama merupakan suatu solusi sosiologis untuk mengatasi konflik-konflik antar agama, dalam pendekatan kajian sosiologi komunikasi yang membantu antar umat beragama untuk meningkatkan kerja sama antara pemeluk-pemeluknya, hingga dengan demikian secara bersama-sama kita dapat menegakkan kemanusiaan, keadilan, perdamaian, dan persaudaraan. Komunikasi pembanguan agama, yang merupakan peroses perkembangan dari kajian lintas agama akan mengatasi rivalitas, penindasan, kebencian, menciptakan harmoni dan menjauhkan sikap hidup yang saling menghancurkan. Dalam konteks ini, komunikasi pembangunan agama dalam membangun toleransi agama bisa dilakukan dalam berbagai bentuk, seperti komunikasi dalam bidang kehidupan,bidang kerja sosial,bidang antar monastik, dialog untuk do'a bersama (istighosah), dan dialog diskusi teologis ${ }^{15}$. Dialog kehidupan terjadi pada tingkat kehidupan sehari-hari, seperti yang terjadi di dalam kehidupan masyarakat, tanpa pembahasan secara formal, di mana setiap orang memerkaya dirinya dengan mengamati dan mencontoh praktik dan nilai dari pelbagai macam agama.

Selama ini Pemerintah maupun para tokoh agama hanya memahami agama-agama dalam pendekatan serimonial, sehingga bentuk komunikasi yang dibangun dalam bingkai regulasi tidak terbangun dari suatu sistem yang kuat, hal ini dikarenakan pemahaman terhadap makna agama dipahami sebatas aspek seremonial. Pada hal konsep "makna" memiliki posisi yang strategis dalam membangun suatu sistem sosial, dalam hal ini sistem regulasi untuk membangun komunikasi lintas agama

${ }^{14}$ Syarat untuk mencapai dialog antar umat beragama adalah dipenuhinya prasyarat dialog, seperti pelaku dialog yang mencapai kesadaran moral otonom, memegang prinsip etika universal, memerhatikan setiap pola tindakan yang dilakukan, menciptakan kondisi dan situasi pembicaraan ideal dengan mengatasi segala macam hambatan, dan kemungkinan distorsi yang terjadi dalam komunikasi. Lihat. Jürgen Habermas, Communication and the Evolution of Society, trans. Thomas McCarty, London: Heinemann, 1979, hlm. 208-209.

15 Mukti Ali, "Dialog dan Kerjasama Agama dalam Menanggulangi Kemiskinan” dalam Weinata Sairin (ed.), Dialog Antar Umat Beragama: Membangun Pilar-pilar Keindonesiaan yang Kukuh, Jakarta: BPK Gunung Mulia, 1994, hlm. 14-16. 
yang memiliki pengaruh yang kuat dalam sistem sosial, meaning atau makna merupakan cara untuk menampilkan kompleksitas dalam sebuah sistem. Padahal seharusnya Pemerintah maupun tokoh agama selaku aktor mampu menangkap dengan baik makna-makna baik berupa simbol-simbol agama yang memiliki makna yang kuat, maupun teksteks doktrin ajaran agama, sehingga sistem komunikasi agama yang terbangun tidak berbicara persoalan baik burus, akan tetapi berbicara pilihan yang berpihak kepada keselamatan umat manusia. Bukan komunikasi lintas agama yang dibangun dalam kekuatan kelompok mayoritas.

Untuk membangun semangat komunikasi pembanguan agama dalam masyarakat majemuk, yang harus dikembangkan adalah sikap saling memberi dan menerima. Sikap tenggang rasa dan menghormati terhadap nilai-nlai perbedaan. Banyak aktor baik Pemerintah maupun tokoh agama yang tidak memahami nilai-nilai perbedaan ini dibangun baik ketika sistem komunikasi lintas agama dijalankan, makanya konsep komunikasi lintas agama di Indonesia menurut penulis perlu memahami aspek sistem komunikasi pembangunan agama dengan baik. Seharusnya bagaimana komunikasi pembangunan agama menjadi suatu akselarator pembangunan keagamaan di Indonesia.

Pembenahan sistem seharusnya menjadi pekerja penting untuk menata ulang sistem komunikasi lintas agama. Komunikasi lintas agama merupakan modal yang sangat berharga bagi kelangsungan kehidupan seluruh masyarakat Indonesia. Sistem komunikasi lintas agama adalah sesuatu yang dinamis yang dapat berubah sesuai dengan perilaku para pendukungnya. Oleh karena itu perilaku para pemimpin agama dan juga tokoh masyarakat selaku aktor memegang peranan penting dalam menjaga iklim kondusif. Di sinilah arti pentingnya hubungan antar umat beragama yaitu hubungan komunikatif yang tidak terbatas pada tokoh agama tapi juga kelibatan para tokoh masyarakat dan pejabat birokrasi pemerintahan.

Sosialisasi komunikasi pembangunan agama dalam membangun penguatan toleransi agama, adalah dimana pemerintah, tokoh agama, tokoh masyarakat yang menjadi aktor berkumpul dalam satu keinginan yakni untuk menghembuskan nafas kerukunan antar umat beragama. Kegiatan ini merupakan wujud komitmen dan kepedulian masyarakat dalam mempromosikan nilai-nilai saling percaya dan saling pengertian diantara berbagai agama. Pemahaman bersama tentang kerukunan harus dilakukan. Pasalnya bangsa ini yang tadinya sangat santun dan sopan, tapi sekarang justru sering terjadi kekerasan yang mengatasnamakan 
agama. Konsepnya kita tahu bahwa agama itu merupakan kompas sebagai penunjuk arah bagaimana kita hidup dengan aman dan damai di permukaan dunia ini. Tapi yang terjadi sekarang agama malah dijadikan alasan untuk melakukan kekerasan.

Pemahaman bersama tidak hanya dilakukan pada momen-momen seremonial agama tertentu, atau stetalah munculnya konflik agama dalam masyarakat. Tetapi komunikasi lintas agama harus dibangun dalam sistem dialog yang memiliki kualitas, dengan mengoptimalkan dialog dengan pemuka agama, tokoh masyarakat dan pendakwa agama serta pemuda dan lapisan masyarakat lainnya. Jadi jati diri merupakan modal dasar kerukunan. Sebab dalam dialog akan ditemukan pikiranpikiran jernih, sekaligus langkah-langkah strategis untuk mengantisipasi munculnya gesekan-gesekan disebabkan masalah agama. Dialog-dialog antarumat beragama dalam komunikasi lintas agama perlu dihidupkan kembali sehingga dapat membangun saling rasa kepercayaan bersama terhadap pentingnya kerukunan, sehingga tidak ada dusta di antara kita, dan tercapai tujuan yang ingin di capai. bagaimana tujuan-tujuan dari pelaksanaan sosialisasi komunikasi lintas agama, dimana untuk mencapai keharmonisan dan perdamaian antar umat beragama dan penanaman nilai-nilai kebersamaan dan diperlukan usaha bersama antara pemuka agama dan pimpinan lembaga negara (eksekutif, legislatif, yudikatif), masyarakat madani, media massa, dan unsur masyarakat lain untuk menghilangkan rasa saling curiga dan membangun sikap saling pengertian. Di tengah-tengah beragam persoalan bangsa tersebut (baik kemiskinan, pengangguran, korupsi, serta ketidakadilan ekonomi, hukum, dan sosial) maka peran tokohtokoh agama selaku aktor sangat penting untuk memberi pencerahan dan suri teladan bagi umat, membangun kepercayaan terhadap diri sendiri dan orang lain.

\section{Agama dan Pembangunan}

Ketika Geertz mengemukakan tesis bahwa agama tidak hanya memainkan peranan dalam menciptakan integritas dan harmoni sosial tetapi juga menjadi faktor konflik dalam masyarakat, analisis antropolog tersebut perlu diterangkan dalam konteks agama sebagai semesta simbol yang terkait dalam proses interaksi struktur sosial masyarakat, yang kemudian secara kategoris dan menjadi kontroversial tercermin dalam pola hubungan santri, abangan dan priyayi dalam konfigurasi sosial 
Gertz $^{16}$. Dengan demikian, ketika kita menyaksikan konflik yang melibatkan sentimen keagamaan, konflik itu pertama-tama perlu dibaca bukan pada asas doktrinal ajaran agama dan aktualisasi agama dalam dimensinya yang intrinsik. Konflik itu perlu dibaca atau diterangkan dalam kerangka perilaku umat beragama yang melibatkan nilai-nilai agama, ideologi, pengetahuan, dan nilai-nilai kultural yang bersarang dalam pengetahuan kebudayaan yang menjadi basis kognisi bagi tindakannya. Lebih kompleks lagi, konflik itu juga perlu dilihat kaitannya dalam situasi dan struktur sosial masyarakat dimana umat beragama itu hidup dengan beragam permasalahan dan tarik menarik kepentingan ekonomi, politik, dan budaya.

Kondisi masyarakat Indonesia yang masih berada pada kehidupan agraris dengan tingkat kualitas hidup yang masih rendah secara sosial ekonomi misalnya, sedikit banyak memberi corak pada kehidupan beragama, termasuk dalam bentuk corak sentimen keagamaan. Kondisi ini dipicu oleh kesenjangan sosial dan struktur politik yang tidak kondusif, sehingga banyak memberikan dorongan pada ekstrimitas, termasuk konflik ${ }^{17}$ yang bercorak atau memperoleh legitimasi sentimen keagamaan. ${ }^{18}$

Agama dalam bentuk apapun dia merupakan suatu kebutuhan ideal manusia, karena itu peran agama sangat menentukan dalam setiap kehidupan, dan tanpa agama manusia tidak akan hidup sempurna ${ }^{19}$. Hal itu berkaitan secara mendasar dalam hakikat kehidupan manusia, bahwa ada sesuatu yang sangat alami pada diri manusia yang sering disebut naluri atau fitrah untuk beragama.

${ }^{16}$ Clifford Geertz, Abangan, Santri, Priyayi Dlam Masyarakat Jawa, Jakarta, Pustaka Jaya, Cet.I. 1981, hlm. 165

${ }^{17}$ Ketika menyakisikan kekerasan atau bahkan konflik yang melibatkan sentimen keagamaan betapapun kompleksnya permasalahan, sesungguhnya keprihatinan yang paling mendalam patut dialamatkan kepada komitmen luhur keberagamaan disetiap lingkungan umat beragama. Legitimasi teologis dan etik semacam apa sesungguhnya yang dijadikan acuan sehingga terlibat konflik yang pada akhirnya menodai keluhuran nilai-nilai agama itu sendiri. Lihat pembakaran dan pembongkaran rumah ibadah umat Kristen di Aceh Singkil di bulan Oktober 2015 yang lalu, begitu juga pembongkaran rumah ibadah umat Islam, yang dilakukan oleh kelompok tertentu yang terjadi di Bitung Sulawesi Utara. Pada kenyataannya regulasi sosial yang dibangun atas nama sentimen terhadap kelompok agama tertentu mampu mengalahkan regulasi yang dirumuskan oleh pemerintah yang terkait dengan membangun harmonisasi kehidupan keberagamaan masyarakat

${ }^{18}$ Haedar Nasir, Agama dan Krisis Kemanusiaan Moderen, Yogyakarta, Pustaka Pelajar, 1997, hlm. 126

${ }^{19}$ Ibid 
Peran agama menjadi sangat penting, ketika agama telah dianut oleh kelompok-kelompok sosial manusia, yang terkait dengan berbagai kegiatan pemenuhan kebutuhan hidup manusia yang kompleks dalam masyarakat. Pada perkembangan yang demikian itulah, kemudian agama menjadi berkaitan langsung dengan kebudayaan masyarakat, sehingga agama dan masyarakat serta kebudayaan mempunyai hubungan timbal balik yang saling pengaruh mempengaruhi.

Menjelaskan filosofis pembangunan di Indonesia adalah terwujudnya masyarakat adil dan makmur berdasarkan Pancasila dan Undang-Undang Dasar 1945. Masyarakat adil dan makmur itu dapat terwujud apabila semua warga negara menyakini Ketuhanan Yang Maha Esa. Penyebutan Tuhan Yang Maha Esa dimaksudkan agar pemahaman inklusif sehingga pemahaman kemajemukan masyarakat diarahkan kepada terbentuknya kesadaran multikulturalisme kosmopolitan. Kesadaran ini telah menyatu dalam berbagai tradisi atau kearifan lokal yang memungkinkan mereka berinteraksi lintas suku, budaya maupun $\operatorname{agama}^{20}$.

Kebijakan pembangunan agama di Indonesia memiliki dua landasan utama yaitu landasan ideal dan landasan instrumental. Landasan ideal adalah cita-cita perjuangan kemerdekaan Indonesia yang dirumuskan dalam lima dasar negara Indonesia yang tersimpul dalam Pancasila. Pancasila diawali oleh kewajiban universal setiap manusia bahwa keberadaan dirinya adalah anugerah Tuhan Yang Maha Esa.

Kementrian Agama merumuskan pembangunan bidang agama memainkan peranan strategis dalam pembangunan nasional Indonesia. Peran strategis tersebut terbentuk karena agama mampu membentuk karakter dan perilaku positif masyarakat, meningkatkan motivasi, serta membatasi perilaku negatif masyarakat. Pada spektrum pembangunan yang lebih essensial, agama memiliki fungsi edukatif (mendidik), fungsi salvatif (penyelamatan), fungsi profetik (kenabian), fungsi integratif (pemersatu), fungsi transformatif (mengubah) dan fungsi solutif (pemecahan masalah). Fungsi fungsi itulah yang saling bertukar peran sesuai dengan situasi dan kondisi sosial yang dihadapi. Berpijak dari pentingnya peranan agama dalam pembangunan bangsa Indonesia, maka pembangunan agama sesungguhnya tidak dapat dipisahkan dengan pembangunan nasional lainnya. ${ }^{21}$

${ }^{20}$ M.Ridwan Lubis, Kebijakan Pembangunan Agama Di Indonesia Dalam Lintasan Sejarah, Jurnal Harmoni Multikultural dan Multirelegius, Volume IX, Nomor 4, April-Juni 2010, hlm. 21

${ }^{21}$ Kementerian Agama R.I, Perencanaan Program dan Anggaran Departemen Agama, 2010, hlm. 1 
Pembangunan agama yang diselenggarakan oleh pemerintah Indonesia merupakan penjabaran pelaksanaan amanat konstitusi. UUD 1945 BAB X A tentang Hak Asasi Manusia, Pasal 28I ayat (1) bahwa hak beragama merupakan salah satu hak-hak asasi manusia yang tidak dapat dikurangi dalam keadaan apapun dan ayat (4) bahwa perlindungan, pemajuan, penegakan, dan pemenuhan hak asasi manusia adalah tanggung jawab negara, terutama pemerintah. Selanjutnya BAB XI tentang Agama pada ayat (1) Negara berdasar atas Ketuhanan Yang Maha Esa dan ayat (2) Negara menjamin kemerdekaan tiap tiap penduduk untuk memeluk agamnya masing masing dan untuk beribadat menurut agamanya dan kepercayaanya itu. Apa yang telah diamanatkan dalam diktum peraturan perundang undangan di atas secara tegas menyatakan bahwa hak beragama merupakan hak asasi dan oleh karenanya merupakan tanggung jawab pemerintah untuk dapat memenuhinya. ${ }^{22}$

Penyelenggaraan pembangunan agama sebagai bagian yang terintegrasi dengan agenda pembangunan nasional harus mampu menciptakan sinergi dengan pembangunan di bidang lainnya. Hal ini secara jelas dinyatakan dalam Undang Undang No. 17 Tahun 2007 tentang Rencana Pembangunan Jangka Panjang Nasional Tahun 2005 2025, bahwa Pembangunan agama diarahkan untuk memantapkan fungsi dan peran agama sebagai landasan moral dan etika dalam pembangunan, membina akhlak mulia, memupuk etos kerja, menghargai prestasi, dan menjadi kekuatan pendorong guna mencapai kemajuan dalam pembangunan. Di samping itu, pembangunan agama diarahkan pula untuk meningkatkan kerukunan hidup umat beragama dengan meningkatkan rasa saling percaya dan harmonisasi antar kelompok masyarakat sehingga tercipta suasana kehidupan masyarakat yang penuh toleransi, tenggang rasa, dan harmonis. ${ }^{23}$

Didasari latar belakang pemikiran di atas, maka perumusan rencana program dan kegiatan pembangunan agama perlu diupayakan untuk mempertegas peran nyata dalam memberikan kontribusi bagi pembangunan nasional secara berkelanjutan. Pada tahap inilah, maka program dan kegiatan pembangunan agama yang menjadi tanggungjawab dan kewenangan Departemen Agama diarahkan untuk memenuhi tuntutan peran tersebut sekaligus menjaga kesinambungan pembangunan yang telah direncanakan baik dalam skenario rencana pembangunan

\footnotetext{
${ }^{22}$ Ibid. hlm. 2

23 'Ibid
} 
jangka panjang, jangka menengah, hingga tahunan.

Kemampuan bangsa untuk berdaya saing tinggi merupakan kunci bagi tercapainya kemajuan dan kemakmuran bangsa. Daya saing bangsa yang tinggi akan menjadikan Indonesia siap menghadapi tantangan globalisasi dan mampu memanfaatkan peluang yang ada. Untuk memperkuat daya saing bangsa, pembangunan nasional diarahkan untuk mengedepankan pembangunan sumber daya manusia (SDM),baik lakilaki maupun perempuan, yang berkualitas. Perkuatan daya saing bangsa mensyaratkan negara yang aman, damai dan demokratis yang masyarakatnya hidup rukun dan harmonis yang didukung oleh pemerataan pembangunan di segala bidang. Disamping itu, jumlah dan persebaran penduduk juga harus dijaga agar terjadi keseimbangan dengan daya dukung lingkungan.

Koentjaraningrat menjelaskan bagaimana nilai agama yang dianut oleh masyarakat Indonesia dari semua lapisan, bagaimana nilai-nilai agama tersebut mampu mendorong manusia Indonesia untuk melihat dan merencanakan masa depannya dengan lebih seksama dan teliti, dan oleh karena itu mengharuskan manusia Indonesia untuk hidup lebih menghargai nilai-nilai kemanusian, mengoptimalkan semangat hidup untuk lebih baik, karena agama apapun yang ada di Indonesia memiliki spirit untuk menjadi manusia yang lebih baik dari segala aspek. Agama memiliki nilai yang sangat strategis dalam memberikan nilai-nilai perubahan dalam masyarakat, hal ini sangat tergantung pada harmonisasi tatanan kehidupan penganut-penganut agama dalam masyarakat. Untuk itu menciptakan situasi kondisi yang menjadi suatu keharusan dalam kehidupan keberagamaan dalam masyarakat, hal ini dikarenakan agama dapat menjadi salah satu yang mendorong semangat pembangunan. Saniotis (2008) menjelaskan dalam topik tulisannya "Making Polders: Social Communication, Relegion, and the Global Environmental" bahwa agama dapat dijadikan sebagai salah satu pendekatan dalam menangani persoalan lingkungan, dalam hal ini agama dijadikan sebagai dasar pembangunan untuk mengatasi persoalan lingkungan tersebut yang sudah menjadi persoalan di berbagai negara. ${ }^{24}$

Pembangunan agama sudah banyak melahirkan berbagai macam bentuk-bentuk regulasi yang tujuannya adalah untuk membangun tatanan peradaban masyarakat yang harmoni dalam kehidupan keberagamaan masyarakat dengan berbagai macam perbedaan yang ada.

${ }^{24}$ Koentjaraningrat, Kebudayaan Mentalitas dan Pembangunan, Jakarta, PT.Gramedia Pustaka Utama, 1997, hlm. 25. 
Akan tetapi yang perlu kita sadari tidak semua implementasi bentuk regulasi tersebut dapat berjalan dengan baik, persoalan ini bermula dari tidak komprehensifnya kajian-kajian sosiologis yang terkait dalam kehidupan keberagamaan masyarakat Indonesia dengan mempertimbangkan berbagai faktor yang terkait dalam konten regulasi yang akan diterapkan. Sehingga dalam lintas sejarah perjalanan bangsa Indonesia pasca kemerdekaan banyak persoalan yang muncul dalam aspek ini.

Secara tekhnis pembangunan agama yang ada di Indoensia tidak terlepas dari nilai-nilai philosofis yang terdapat dalam Pancasila sebagai dasar negara dan pandangan hidup masyarakat Indonesia dalam melakukan interaksi dalam tatanan sistem sosial, begitu juga dengan pemerintah sebagai suatu landasan philosofis dalam mengkaji semangat nilai pembangunan yang direncanakan. Persoalan pembangunan dalam sektor agama terkait dengan penguatan toleransi agama baik secara struktural maupun kultural, ketika terjadi politisasi dari berbagai muatan kebijakan dalam pembangunan agama, politisasi ini muncul ketika aktor yang terlibat lebih mengedepankan kepentingan kelompok maupun individu, sehingga banyak kita jumpai pelanggaran-pelanggaran hakhak sipil masyarakat yang secara substansi telah bertentangan dengan semangat-semangat nilai philosofis yang menjadi dalam dasar melakukan pembangunan khususnya pada sektor keagamaan.

\section{Agama dan Sistem Sosial Masyarakat}

Dalam setiap masyarakat, menurut pendekatan struktural fungsional, akan selalu ditemukan adanya sistem nilai sebagai hasil konsensus bersama (collective consciousness) semua anggota masyarakat. Masyarakat itu selalu mempunyai keinginan-keinginan yang hendak dicapai, dan untuk ini telah disediakan seperangkat cara penyampaiannya. Permulaan perilaku oleh kaidah sosial hasil konsensus bersama itu mempunyai kekuatan memaksa dan ini disadari oleh semua anggota masyarakat, bahwa memang seperti itulah seharusnya (self enforcing). Dalam keadaan seperti ini, sistem nilai itu bersifat fungsional dan mempunyai kekuatan integratif. Sistem nilai itu bersumber pada pola-pola budaya yang meliputi; belief system, system of exspressive symbolism, dan system of value orientation standars. ${ }^{25}$

${ }^{25}$ Dewi Narwoko, Bagong Suyanto, Sosiologi Teks Pengantar Dan Terapan, Jakarta, Kencana Media Group, Cet. IV, 2004, hlm. 262. 
Dalam sistem kepercayaan, sistem simbolik dan standar orientasi nilai yang sama memungkinkan berlangsungnya bentuk hubungan sosial, interaksi sosial, sehingga proses sosial dapat berjalan dengan lancar. Proses sosial telah diformat sedemikian rupa oleh sistem budaya dan sistem kepercayaan yang ada sehingga setiap orang sudah mengerti bagaimana seharusnya berhubungan dengan orang lain. Setiap masyarakat berusaha mengintegrasikan diri dengan sistem nilai yang ada melalui proses sosialisasi dan institusionalisasi tersebut. Kesamaan sikap dan ide dalam merespon orang lain dalam proses sosial itulah yang oleh W.I. Thomas disebut sebagai coomon definitaion of the situation.

Kalau sistem sosial bisa diwarnai bahkan dibentuk oleh nilai agama, maka yang menarik dipertanyakan adalah mungkinkah agama yang dinilai lengkap membawa nilai-nilai sebagaimana yang ada dalam sistem sosial bisa menggantikan sistem sosial? Dengan kata lain, apakah sistemsistem non agamis (seperti kapitalisme, liberalisme, komunisme, atau sosialisme) yang selama ini hidup, berkembang dengan segala dinamikanya dalam sistem sosial bisa digantikan dengan agama? Untuk menjawab itu, kita bisa berdebat panjang. Tetapi yang jelas, ada yang mengatakan bahwa agama tidak akan pernah bisa menggantikan sistem sosial, apalagi sebaliknya. Sebab, masing-masing ada dan tercipta sesuai tugasnya masing-masing, sistem sosial untuk mengatasi problematika keagamaan, sedangkan agama untuk mengatasi dunia misteri (ukhrawr), antara misteri dan materi jelas tidak sama.

Di dalam masyarakat primitif, agama telah meluas dari berbagai kegiatan dan hubungan sosial masyarakat. Ada dua faktor yang memacu perubahan dari situasi agama primitif yang berciri sebagai kelompok sosial ke arah agama yang terorganisasi secara khusus. Pertama, meningkatkan secara total "perubahan batin" atau kedalaman beragama, karena pembagian kerja dalam masyarakat kian berkembang yang kemudian melahirkan alokasi fungsi, alokasi fasilitas, serta sistem imbal jasa yang kian ruwet, maka masyarakat cenderung mengembangkan suatu tingkat spesifikasi fungsi yang lebih tinggi. Kemudian tampillah kelompok-kelompok dengan tujuan yang lebih jelas dan terperinci untuk menjelaskan berbagai kegiatan, seperti produksi, pendidikan dan sejenisnya yang sebelumnya ditangani oleh kelompok-kelompok yang lebih kabur seperti keluarga. Agama yang terorganisasi secara khusus ini lahir sebagai akibat dari kecenderungan umum ke arah pengkhususan fungsional. Kedua, meningkatnya pengalaman keagamaan yang mengambil bentuk berbagai organisasi keagamaan baru. Dengan demikian perkembangan organisasi keagamaan yang khusus 
menunjukkan pengaruh umum terhadap proses kemasyarakatan dan perubahan-perubahan kedalaman agama. Ritus, keyakinan, dan corak organisasi keagamaan yang baru akan berbeda dari masing-masing kelompok keagamaan yang ada dalam masyarakat. Pada umumnya agama baru itu menunjukkan pemisahan dengan masa lalu dan memuliakan semangat kesatuan dan persatuan baru.

Bentuk dan sifat keyakinan masyarakat kian berubah seiring dengan semakin majunya pengetahuan manusia. Pengetahuan yang semakin maju dan berkembang, menyebabkan semakin banyak fenomenafenomena alam yang diungkap, yang sebelumnya di-Tuhan-kan, kian menjadi bagian realitas biasa ${ }^{26}$. Karena manusia selalu memerlukan keyakinan, maka manusia mulai mencari "totem-totem" baru sampai akhirnya ditemukan agama samawi-Islam, Kristen, misalnya. Agama Samawi yang diturunkan Tuhan, walau bersumber sama, dari Tuhan, namun apresiasi dan pemaknaannya menjadi beragam seiring dengan karakteristik dan kemampuan serta pengetahuan masyarakat. Karena itu, sering dijumpai ada masyarakat yang sama-sama beragama Islam, tetapi penafsirannya berbeda-beda, maka pengalamanya berbeda juga.

Sejarah Eropah Barat menunjukkan bahwa dalam kondisi teraliensi akibat industrialisasi, masyakat semakin meninggalkan keyakianan keagamaan (gereja) dan sebagai gantinya memalingkan ke insititusiinstitusi sosial sekuleritas, ilmu pengetahuan dan teknologi. Agama dengan semangat yang dikandungnya bisa menjadi faktor berperan untuk mengikat manusia dari perjalanan hidup yang kian semrawut. Namun demi kepentingannya, musuh-musuh kemanusiaan telah menjadikan agama sebagai alat untuk memenuhi kebutuhan akhirat saja, dan ketika agama dipisahkan dari kehidupan, sesungguhnya motivator kehidupan telah dipreteli dan agama telah berbalik maknanya, maka saat itu agama telah menjadi musuh manusia dan menjadi petaka besar bagi sirnanya nilai-nilai kemanusiaan ${ }^{27}$

Lebih spesifik lagi, Broom dan Selznick menunjukan beberapa fungsi agama sebagai:1. Overcomin pain, fear, and an anxiety, 2. Making the world understandable, 3. Supporting social norms and values. 4. Maintaining sosial unity Broom and Selznick, seiring dengan Broom, Green mengemukan fungsi agama sebagai : 1 . To rationalized and make bearable individual suffering in the known world. 2. To enhance self-impotence, 3. To knit the social values of a society into a cohesive whole. ${ }^{28}$

${ }^{26}$ Ibid. hlm. 268.

${ }^{27}$ Ibid. Hlm. 269.

${ }^{28}$ Ibid. 
Apakah dengan adanya fenomena bangkitnya kesadaran beragama seperti terjadi belakangan ini berarti agama merupakan alternatif dari sistem-sistem lain seperti kapitalisme, komunisme, atau sosialisme yang belakangan banyak dinyatakan gagal mendatangkan ketentraman hidup manusia? Tantangan pertanyaan ini, ada sebahagian orang yang menyetujuinya, dan sebahagian lain meragukannya bahkan menolaknya.

Jika agama ditempatkan dalam posisi sebagai ideologi, maka agama dapat berfungsi sebagai faktor penyebab (independent variable) terhadap perubahan dari alternatif sistem yang ada. Artinya, agama bisa mempengaruhi jalannya suatu perubahan dalam masyarakat. Namun, agama sebagai suatu ideologi juga bisa difungsikan sebagai sarana mempertahankan status quo yang oleh Peter L Berger disebut sebagai world-maintaining force, pengambat suatu perubahan, dan intinya berarti agama tetap mempertahan suatu bentuk sistem yang lama.

Salah satu pemikir yang menyetujui bahwa agama bisa berfungsi sebagai alternatif dari sistem yang lain adalah seorang filsuf sejarah, Pitrim Sorokin. Ia mengatakan bahwa kebudayaan berkembang melalui tiga tahap. Tahap pertama, adalah apa yang Ia sebut dengan tahap "ideasional" antara lain ditandai dengan satu prinsip pemersatu kebudayaan. Ditekankannya bahwa dimensi supra indrawi, suprarasional, tahap kedua, tahap idealistic yang memadukan inderawi dengan supra inderawi, ketiga, perkembangan kebudayaan akan bergeser menuju ke tahap baru, yang ia sebut dengan sensate culture, yang antara lain ditandai oleh karakteristik indrawi, empiris dan sekuleristis. Pada puncak perkembangan budaya-budaya itu, akan dicapai suatu tahapan budaya baru yang oleh Sorokin disebutnya sebagai supra-concious level.

Sementara pemikir lain yang meragukan kemampuan agama sebagai alternatif dari sistem yang ada adalah Sastrapratedja. Ia secara tegas tidak sependapat dengan anggapan di atas, termasuk pendapat Sorokin. Memang, ia mengakui pengalaman relegius bisa memperkaya manusia, namun tidak memecahkan masalah. Terlalu naif sebab permasalahan manusia sendiri manusia terlalu kompleks. Ketidak mampuan agama memecahkan masalah tersebut, menurutnya karena beberapa faktor: 1. Agama merupakan sistem makna yang memberikan interpretasi yang menyeluruh terhadap kenyataan. Jadi fungsinya terbatas. Ia hanyalah salah satu dimensi saja dari kehidupan manusia, 2. Agama sebagai realitas historis juga memiliki keterbatasan sendiri, ambigus, pathogenis, dan terapeutis. Religi, katanya dapat "membutakan", memberikan suatu kesadaran palsu, menciptakan dependensi, melegetimasi ketidakadilan. Namun, ia juga mengakui bahwa dengan 
religi orangpun bisa "melihat", menjadi lebih sehat, membebaskan, bahkan menjadi katalis bagi suatu perubahan dan menghasilkan kritik, termasuk kritik terhadap diri sendiri.

Agama ada diperuntukkan bagi manusia dalam kehidupan, bukan sebaliknya manusia untuk agama. Ini artinya bagaimana agama didayagunakan untuk mengantarkan manusia dalam kehidupan di dunianya dan mengantarkannya mempersiapkan kehidupannya di akhirat. Pengertian ini membawa konsekwensi bahwa kesadaran beragama bukan malah membelenggu manusia dalam fanatisme agama yang sempit dan terkesan ekstrem, namun justru membawa pada arah pembebasan manusia dari keterbelengguannya baik pada nilai agamanya sendiri maupun pada dunia material duniawi.

Menganalisis fenomena sistem sosial keberagamaan merupakan salah satu bahagian yang penting untuk menganalisis dari mana memulai membangun penguatan toleransi agama, terutama dalam pendekatan struktural masyarakat ${ }^{29}$ serta peranan sistem-sistem dan sub sistem lembaga, yang terlibat sebagai aktor pelaku yang mengerakkan sistemsistem penguatan dalam membangun toleransi agama. Dalam sistem sosial masyarakat, dapat menata proses komunikasi pembangunan agama, baik dari kontent isi terhadap bentuk dari regulasi yang akan disampaikan dalam sistem komunikasi pembangunan agama, dengan mempertimbangkan kondisi komunikan baik secara struktural dalam konteks kepemerintahan maupun kultural dalam tatanan sistem masyarakat sebagai objek dari penerapan regulasi yang terkait dalam melakukan penguatan toleransi agama di masyarakat.

\section{Kesimpulan}

Komunikasi pembangunan agama merupakan suatu konsep kajian studi yang sangat diperlukan dalam membangun sistem pembangunan agama dengan melihat berbagai sistem maupun sub sistem yang memiliki

${ }^{29}$ Pluralitas budaya bangsa merupakan kekayaan yang sangat berharga bagi bangsa Indonesia, terutama karena dalam budaya Indonesia memiliki nilai-nilai yang sangat fungsional untuk memperkokoh integritas nasional, misalnya budaya gotong royong, tenggang rasa, dan musyawarah mufakat. Dalam kaitannya dengan pencegahan konflik antar umat beragama, tentu saja nilai-nilai yang fungsional untuk memperkokoh integrasi nasional tersebut diharapkan dapat digali kembali dan disesuaikan dengan nilai-nilai modernitas bangsa oleh para budayawan atau para pakar budaya. Lihat. Imam Tolkhah, Mewaspadai dan Mencegah Konflik. Antar Umat Beragama, Jakarta, Badan Litbang Agama dan Diklat Keagamaan Proyek Peningkatan Kerukunan Hidup Umat Beragama, 2001, hlm. 135 
keterkaitan dalam melakukan penguatan toleransi agama khususnya di Indonesia. Masing-masing sub sistem yang terlibat memiliki spesipikasi kajian tersendiri untuk di analisis dalam menemukan formulasi yang tepat dalam menentukan strategi pembangunan agama di Indonesia.

Kajian aktor dapat diihat dari berbagai perspektif untuk melihat berbagai kebijakan yang telah dilakukan oleh aktor pembangunan baik secara individu maupun kelembagaan, terlebih pola-pola interpensi yang mempengaruhi aktor mulai dari memahami kontent pembangunan agama, maupun bentuk regulasi, termasuk institusi kebijakan, dan legitimasi politik. Semuanya itu menjadi suatu kajian yang komprehensif untuk menganalisis komunikasi pembangunan agama, yang selama ini terkesan parsial, dan komunikasi yang bersifat parsial serta tidak memiliki muatan informasi pesan-pesan yang kuat dalam pendekatan komunikasi pembangunan agama.

\section{Daftar Pustaka}

Clifford Geertz, Abangan, Santri, Priyayi dalam Masyarakat Jawa, Jakarta, Pustaka Jaya, Cet.I. 1981

Coward, Pluralisme dan Tantangan Agama-agama, Yogyakarta: Kanisius, 1989

De Grote Oosthoek, Encyclopedie en Woordenboek,sDeeln16, Oosthpek's Uitgeversmaatschappij BV, Utrechht, 1976

Dewi Narwoko, Bagong Suyanto, Sosiologi Teks Pengantar dan Terapan, Jakarta, Kencana Media Group, Cet. IV, 2004

Djohan Effendi, Pluralisme dan Kebebasan Beragama, Yogyakarta, Institut DIAN/Interfide, Cet.IV, 2013

Fitzgerald K. Sitorus, Masyarakat Sebagai sistem-Sistem Autopoiesis, Tentang Teori Sistem Sosial Nikhas Lumann. Dalam. Jurnal Filsafat, Driyarkara, Kebaruan Teori Sistem Niklas Luhman, Thn.XXIX no.3/2008

Haedar Nasir, Agama dan Krisis Kemanusian Moderen, Yogyakarta, Pustaka Pelajar, 1997

Hasan Sazali. Penguatan Toleransi Agama dalam Komunikasi Pembangunan Agama Studi Pemerintah Kota Bogor dan Yogyakarta Disertasi, Jurusan Penyuluhan dan Komunikasi Pembangunan, sekolah Pascasarjana Universitas Gadjah Mada Yogyakarta, 2015

http://www.jabarantha.co.cc/2011/06/membangun-komunikasi-lintasagama.html. di akses 3 Januari 2014. 
Imam Tolkhah, Mewaspadai dan Mencegah Konflik. Antar Umat Beragama, Departemen Agama R.I Badan Litbang Agama dan Diklat Keagamaan Proyek Peningkatan Kerukunan Hidup Umat Beragama, Jakarta, 2001

Jürgen Habermas, Communication and the Evolution of Society, trans. Thomas McCarty , London: Heinemann, 1979

Kaushik Basu, Preludo to Political Economy, A Study of The Social and Political Foundation of Economics. Oxford. hlm. 36-37.

Kementerian Agama R.I, Perencanaan Program dan Anggaran Departemen Agama, 2010

M.Ridwan Lubis, Kebijakan Pembangunan Agama di Indonesia dalam Lintasan Sejarah, Jurnal Harmoni Multikultural dan Multirelegius, Volume IX, Nomor 4, April-Juni 2010

Mukti Ali, "Dialog dan Kerjasama Agama dalam Menanggulangi Kemiskinan" dalam Weinata Sairin (ed.), Dialog Antar Umat Beragama: Membangun Pilar-pilar Keindonesiaan yang Kukuh , Jakarta: BPK Gunung Mulia, 1994

Nurhadi M. Musawir, Agenda Pemuka Agama dan Elit Politik dalam Membangun Kerukunan Hidup Antar Umat Beragama di Indonesia, Jurnal Multikultural dan Relegius, Harmoni, Volume II, Nomor 7, Juli-September 2003, Puslitbang Kehidupan Beragama Badan Litbang Agama dan Diklat Keagamaan Departemen Agama R.I

William Outhwaite, The Blackwell Dictionary Of Modern Social Thought, Terjemahan, Ensiklopedi Pemikiran Sosial Modern, Jakarta, Kencana Prenada Media Group,, Cet. I, 2008 